\title{
Broadband Piezoelectric Energy Harvesting Technology
}

\author{
Dong-Gyu Lee ${ }^{1,3}$, Yeon-Jeong Yee ${ }^{2,3}$ and Hyun-Cheol Song ${ }^{3, \uparrow}$
}

${ }^{1}$ Material Science and Engineering, Korea University, ${ }^{2} \mathrm{KU}$-KIST Graduate School of Converging Science and Technology, Korea University, ${ }^{3}$ Center for Electronic Materials, Korea Institute of Science and Technology.

\section{광대역 압전 에너지 하베스팅 기술}

\author{
이동규,3, 이연정 23, 송현철 $3, \dagger$ \\ 1고려대학교 신소재공학과, ${ }^{2} \mathrm{KU}-\mathrm{KIST}$ 융합대학원, ${ }^{3}$ 한국과학기술연구원 전자재료연구단
}

(Received February 21, 2019; Accepted March 5, 2019)

\begin{abstract}
s
Recent advances in low-power sensors and transmitters are driving the search for standalone power sources that utilize unused ambient energy. These energy harvesters can alleviate the issues related to the installation and maintenance of sensors. Particularly piezoelectric energy harvesters, with the ability to convert ambient mechanical energy into useful electricity, have received significant attention due to their high energy density, low cost and operational stability over wide temperature and pressure conditions. In order to maximize the generated electrical power, the natural frequency of the piezoelectric energy harvester should be matched with the dominant frequency of ambient vibrations. However, piezoelectric energy harvesters typically exhibit a narrow bandwidth, thus, it becomes difficult to operate near resonance under broadband ambient vibration conditions. Therefore, the resonating of energy harvesters is critical to generate maximum output power under ambient vibration conditions. For this, energy harvesters should have broadband natural frequency or actively tunable natural frequency with ambient vibrations. Here, we review the most plausible broadband energy harvesting techniques of the multi-resonance, nonlinearity, and self-resonance tuning. The operation mechanisms and recent representative studies of each technique are introduced and the advantages and disadvantages of each method are discussed. In addition, we look into the future research direction for the broadband energy harvester.
\end{abstract}

Keywords: Piezoelectric energy harvesting, Broadband resonance, Multimodal, Nonlinearity, Self-resonance tuning 


\section{1. 서론}

최근 4차 산업혁명 시대를 맞이하여, 모든 사물들이 인 터넷으로 연결되는 사물 인터넷(Internet of Things; IoT) 기술이 크게 주목 받고 있다. 그러나 이러한 IoT 기 술의 저변 확대 및 보편화를 가로막는 가장 큰 장애물로, IoT를 구성하는 핵심 요소인 센서 및 무선 송수신 장치들 이 전원선이나 배터리로부터 자유롭지 못하다는 것이다. 이러한 배터리는 지속적인 사용을 위해서 충전을 하거나 교체하는 작업이 필요하며, 전원선 연결을 위해서는 복잡 한 배선 작업이 필요하다. 원거리에서 구조를 모니터링하 는 센서(Health monitoring sensor)나 지리적으로 접근 하기 어려운 곳에 설치된 온도 - 습도 센서의 배터리를 충 전하거나 교체하는 작업 및 전원선을 연결하는 일은 시간 과 비용이 많이 들고, 경우에 따라서는 이러한 작업들이 불가능할 수도 있다. 예를 들면 해저 깊은 곳, 넓는 사막 지역, 원자로 안, 높은 건물의 외벽, 극지방 등과 같이 위 험하거나 환경이 가혹하고 설치 지역이 광활하여 사람의 접근이 힘든 곳에서 배터리를 교체하거나 전원선을 연결
하는 일은 거의 불가능에 가까운 일이다. 또한 도심 지역 에 있어서도 수백, 수천 개의 센서가 설치된 무선센서 네 트워크(WSN: Wireless Sensor Network) 환경에서는 시간과 비용을 따질 때 이러한 작업들은 굉장히 비효율적 인 일이다. 그러므로 이러한 대규모 센서 네트워크 환경 이나 사람이 접근이 힘든 곳에서 안정적인 전원을 공급하 기 위해서는, 해당 위치에서 사용 가능한 모든 형태의 에 너지원들을 전기에너지로 변환할 수 있는 자가 발전기 (On-site generators)의 개발이 필요하다. 최근 저전력 VLSI 기술의 급속한 발전으로 인해 초저전력 집적회로 및 센서의 구현이 가능하게 되었으며, 이러한 소자들은 불과 $10 \sim 100 \mu \mathrm{W}$ 의 전력으로 구동이 가능하다. 이러한 전자소자들의 저전력화는 에너지 하베스팅(Energy harvesting) 기술을 이용한 온 보드 전원(On-board power source)의 실현 가능성을 높여주었으며, 복잡한 배선이나 배터리가 필요 없는 자율 전원 센서(Standalone sensor) 및 네트워크 시스템의 토대를 마련하였다고 할 수 있다.

에너지 하베스팅(Energy harvesting) 기술이란, 주변
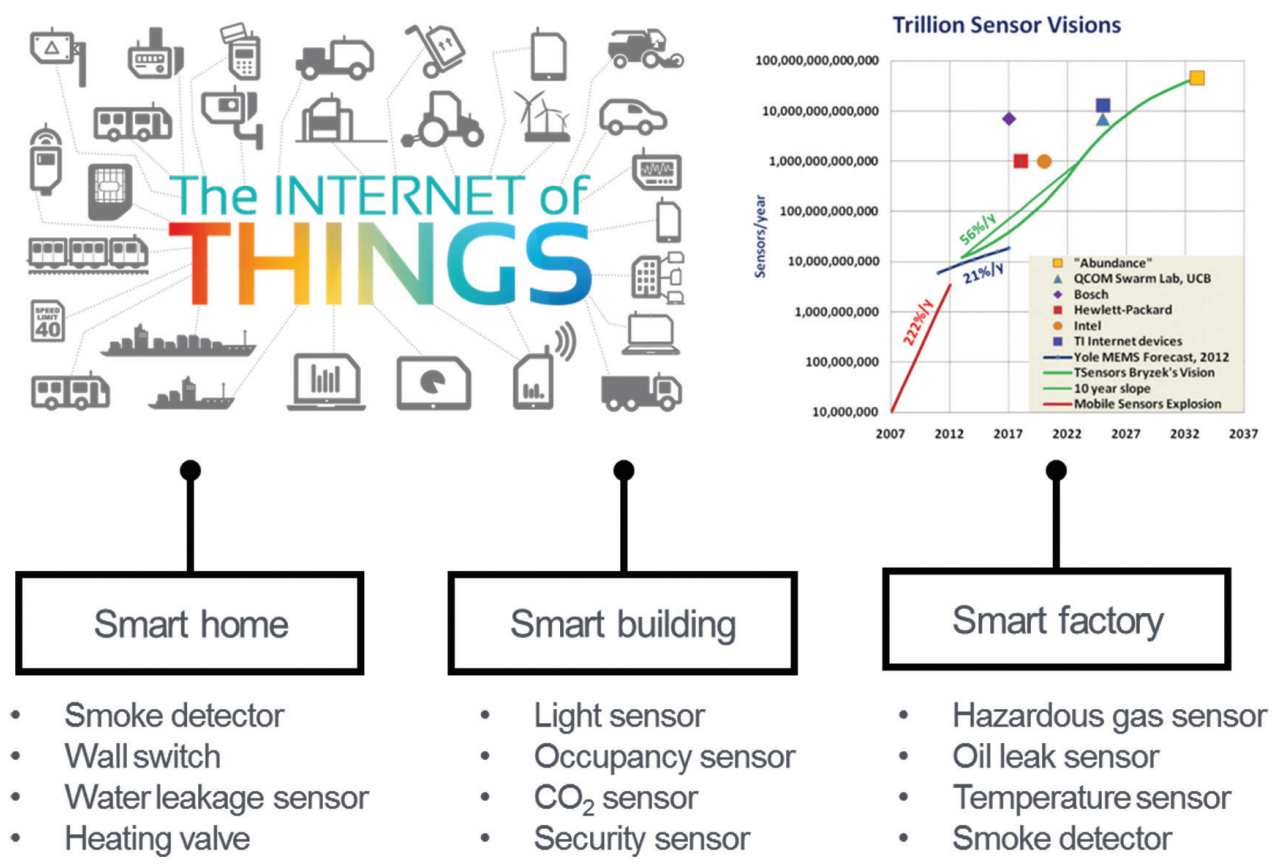

Fig. 1. 자율 전원 사물 인터넷(Internet of Things, loT) 및 연간 loT 센서 사용량 예측. 


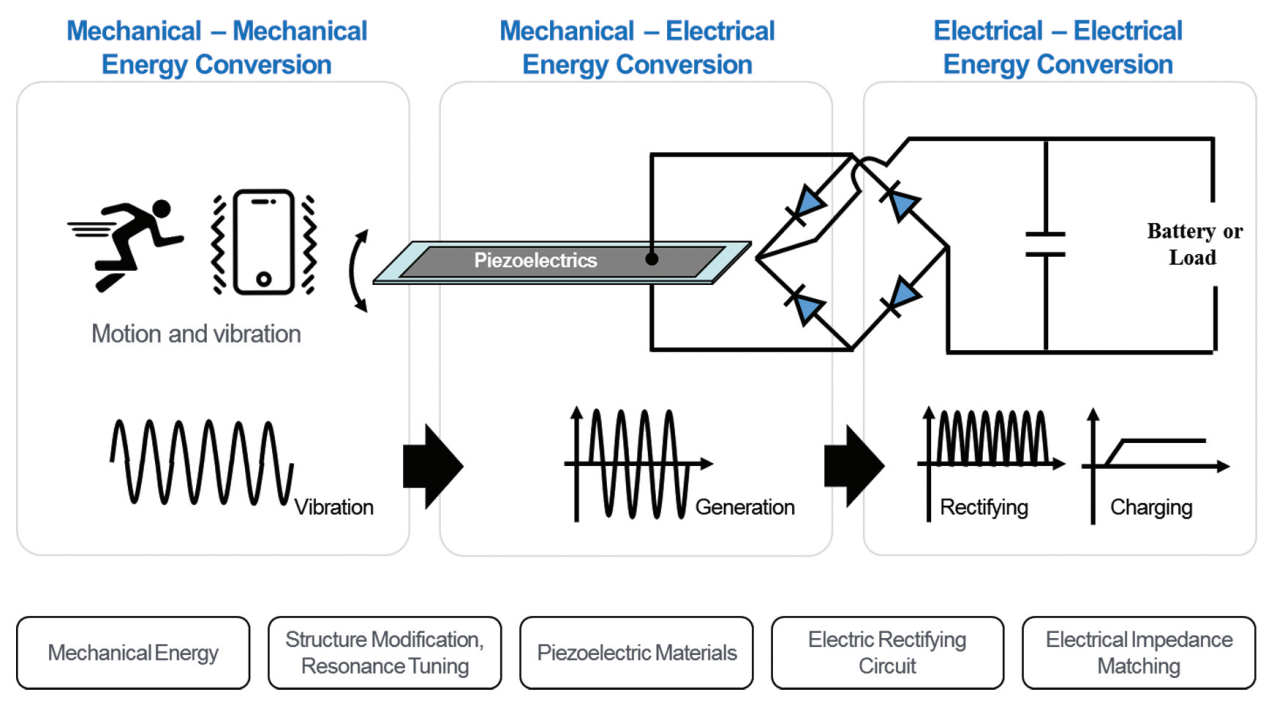

Fig. 2. 압전 에너지 하베스팅에서의 에너지 변환 및 에너지 흐름도.

환경에서 버려지는 미사용 에너지를 수확하여 전기에너 지로 변환하여 이용하는 것을 말한다. 미사용 에너지는 산업기계, 자동차, 건축 구조물, 보일러 등의 여러환경에 서 진동, 열, 빛, 전자기파 등의 여러 형태로 생성될 수 있 다. 이러한 여러 종류의 에너지원 중에서, 기계적 에너지 는 산업용 기계, 운송 시스템, 가전 제품 및 인간의 움직 임 등과 같이 우리 주변에 흔히 존재하고, 다른 에너지들 에 비해 에너지 밀도가 비교적 크다는 장점을 가지고 있 다. 또한 기계적 에너지 하베스팅(Mechanical energy harvesting)은 태양전지와 달리 실내 · 외 환경 조건에 크게 영향을 받지않으며, 산업현장이나 실외의 거칠고 먼 지가 많은 가혹한 환경에서도 잘 작동 할 수 있다. 기계적 에너지를 전기 에너지로 변환하는 방법에는 압전 (Piezoelectric), 전자기(Electromagnetic), 마찰전기 (Triboelectric) 등의 여러가지 에너지 변환 메커니즘이 있다. 이러한 에너지 변환 메커니즘 중에서, 압전 에너지 하베스팅(Piezoelectric energy harvesting) 기술은 높 은 전기-기계 변환 효율, 높은 에너지 밀도, 온 · 습도 안 정성 및 소자 구조의 단순성으로 인해 실용화 가능성이 가장 높으며, 최근까지 가장 많은 연구가 진행되고 있 다. ${ }^{1-3)}$

압전 에너지 하베스팅은 Fig. 2의 에너지 흐름도에서
보는 바와 같이, 크게 3단계에 걸쳐 에너지 변환(Energy conversion)이 일어난다. ${ }^{2)}$ 각각의 에너지 변환 단계에서 는 불가피하게 에너지 손실이 발생하며, 주변의 제한된 에너지원으로부터 최대한의 전기 에너지를 얻기 위해서 는, 각 단계의 에너지 변환 효율을 증가시켜야 한다. 첫 번째 에너지 변환 단계는 기계적 에너지에서 기계적 에너 지로의 변환이며, 에너지 하베스터가 주변의 기계적 에너 지를 얼마나 효율적으로 흡수할 수 있느냐와 관련이 있 다. 이 단계에서 에너지 변환 효율을 높이기 위해서는, 에 너지 하베스터의 고유진동수를 조절하여 공진을 유도하 는 등의 하베스터 구조를 주변 진동에 맞춰 최적화하는 작업이 필요하다. 두번째는 기계-전기 에너지 변환 단계 로 에너지 변환 재료인 압전재료와 밀접한 관련이 있으 며, 이 단계의 에너지 변환 효율을 향상시키기 위해서는 압전재료의 에너지 하베스팅과 관련된 물성을 향상시켜 야 한다. 그리고 마지막은 전기-전기 에너지 변환 단계 로, 압전체로부터 생성된 교류 형태의 전기에너지를 배터 리에 충전하거나 소자에 이용하기 위해 직류 형태의 전기 에너지로 변환하는 것이다. 이를 위해서 정류회로나 DC-DC 컨버터(Converter) 등의 전기회로가 사용되며, 여기에서 에너지 손실이 발생하게 된다. 이 단계에서 에 너지 변환 효율을 높이기 위해서는 저에너지 손실 전기회 


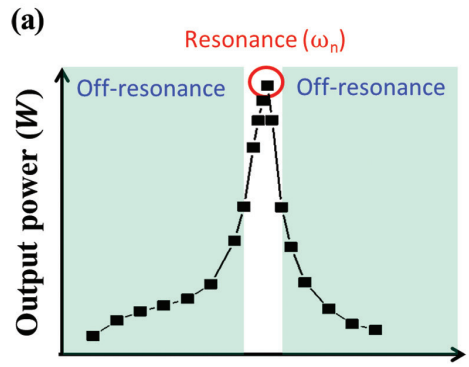

Frequency $(\mathrm{Hz})$ (b)

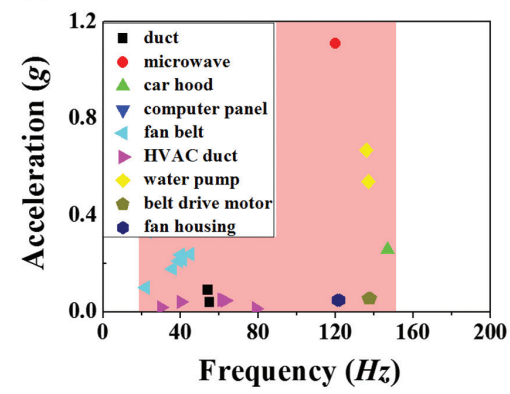

Fig. 3. (a)일반적인 압전 에너지 하베스터의 주파수 응답 특성. (b)주변의 이용한 가능한 진동들의 가속도 및 주파수.

로의 개발이 필요하다. 본고에서는 압전 에너지 하베스팅 에서 가장 중요한 에너지 변환의 단계인 기계적-기계적 에너지 변환에 대한 내용을 중점적으로 다루고자 한다.

주변의 기계적 에너지로부터 생성 전력을 최대화하기 위해서는 압전 에너지 하베스터가 주변 진동과 공진 (Resonance) 상태가 되어야 한다. 에너지 하베스터의 고 유진동수(Natural frequency)와 가해지는 진동의 주파 수가 일치할 때 공진이 일어나며, 이 때 외부의 기계적 에 너지가 최대로 전달될 수 있다. 대부분의 압전 에너지 하 베스터는 변위를 증폭시키기 위해 외팔보(Cantilever) 형태의 구조를 가진다. 일반적으로, 이러한 외팔보 구조 의 압전 에너지 하베스터는 오일러-베르누이 빔 방정식 (Euler-Bernoulli beam equation)을 따르며, 일반적 으로 Fig. 3 (a)에서와 같이 공진 주파수 부근에서 굉장 히 좁은 대역 $(2 \mathrm{~Hz}$ 이내)의 응답 특성을 나타낸다. 또한 공진 주파수를 벗어난 비공진(Off-resonance) 영역에
서는 공진에 비해 출력전압이 크게 떨어지는 것을 알 수 있다. 그와는 반대로, Fig. 3 (b)에 나타난 것처럼, 우리 주변의 이용 가능한 진동들은 넓은 주파수 범위(수십 내 지 수백 $\mathrm{Hz}$ )를 가지고 분포하고 있다. 따라서 실제 응용 조건에서 에너지 하베스터를 이용하기 위해서는, 주변 진 동에 맞춰 에너지 하베스터의 고유 진동수를 조정하는 작 업이 필요하다. 그러나 에너지 하베스터를 사용환경에 맞 춰 일일이 조정해야하는 것은 굉장히 비효율적인 일이며, 이는 실용화에 큰 장애물이 될 수 있다. 그러므로 넓은 영 역의 고유 진동수 및 단순한 장착 조건을 가지는 광대역 에너지 하베스터(Broadband energy harvester)를 개발 하는 것이 훨씬 더 바람직하다고 할 수 있다. 이러한 이유 로 인해 최근 광대역 에너지 하베스터 개발에 대한 연구 가 세계적으로 활발하게 진행 중에 있다.

현재의 광대역 압전 에너지 하베스팅 기술의 연구 방향 은 크게 에너지 하베스터의 다중 공진(Multiple (a)

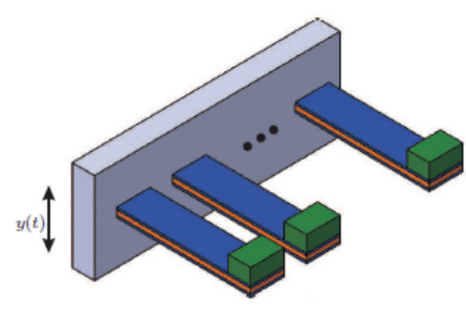

(b)

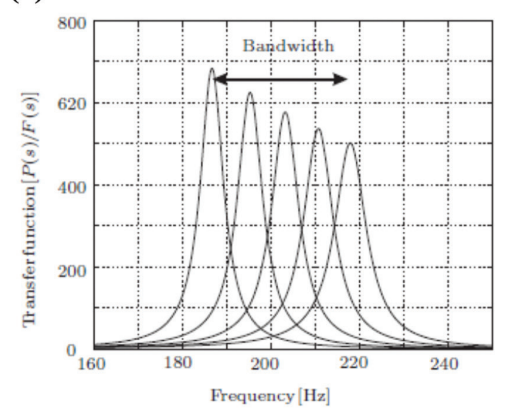

Fig. 4. (a)에너지 하베스터 배열을 보여주는 모식도. (b)에너지 하베스터 어레이의 주파수에 따른 전달 함수(Transfer function). ${ }^{4)}$ 
(a)

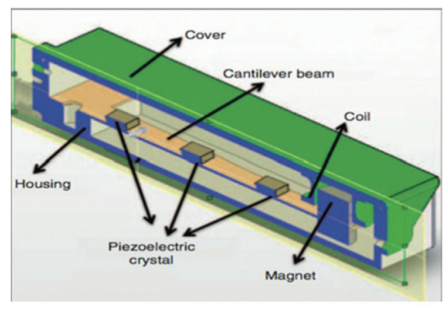

(b)

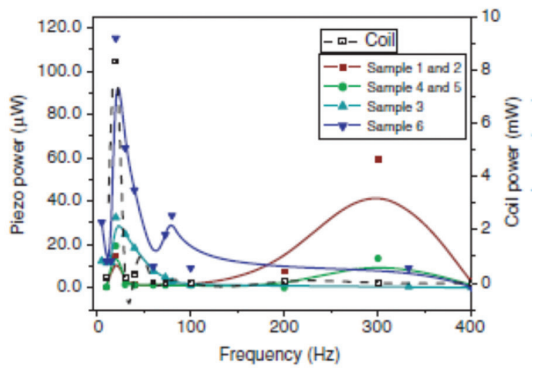

Fig. 5. (a)다중 공진 모드를 이용한 에너지 하베스터의 모식도. (b)다중 공진 모드의 주파수에 따른 출력파워.5)

resonance)을 이용하는 방법, 에너지 하베스터 구조에 비선형성(Nonlearity)을 유도하는 방법, 에너지 하베스 터의 고유진동수를 환경에 맞추어 자동으로 조절하는 자 가 공진 튜닝(Self-resonance tuning) 방법 등으로 나 누어 진행되고 있다. 본고에서는 광대역 압전 에너지 하 베스팅 기술의 각 연구 방법에 따른 개발 이슈 및 최신 연 구 동향에 대해서 소개하고 향후 발전 방향에 대하여 전 망해 보고자 한다.

\section{2. 다중 공진을 이용한 광대역 에너지 하베스팅}

에너지 하베스터의 공진 주파수 대역폭(Resonance frequency bandwidth)을 넓히는 가장 손쉬운 방법은 공 진 주파수가 다른 여러 개의 에너지 하베스터를 동시에 사용하는 것이다. Fig. 4 (a)는 외팔보 구조의 에너지 하
베스터 배열(Energy harvester array)을 보여주는 모식 도이다. ${ }^{4)}$ 외팔보 구조의 에너지 하베스터는 길이 등의 형 태를 변화시키거나, 외팔보 끝에 부착된 표준질량(Proof mass)의 무게를 변화시킴으로써, 고유진동수를 쉽게 조 정할 수 있다. 이러한 방법을 이용하여 여러 개의 에너지 하베스터의 고유진동수를 순차적으로 변화시키고, 이를 나열하여 하나의 모듈로 만들게 되면, Fig. 4 (b)에서와 같이, 전체 모듈은 넓은 대역의 공진 주파수를 가진다. ${ }^{4)}$ 그러나 하나의 주파수에서 하나 또는 두개의 에너지 하베 스터만 동작하기 때문에, 에너지 밀도(Energy density) 가 크게 떨어지는 단점이 있다. 그리고 나열된 에너지 하 베스터들은 출력전압의 위상(Phase)과 임피던스 (Impedence)가 서로 다를 수 있기 때문에, 최대 출력을 얻기 위해서는 나열된 개별 에너지 하베스터가 별도의 전 기회로들을 사용해야 된다. 하지만, 이는 장치의 복잡성 (a)

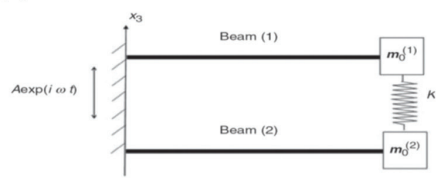

(b)

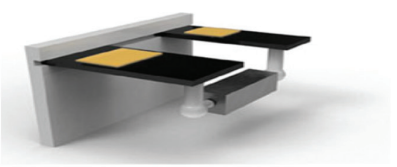

(c)

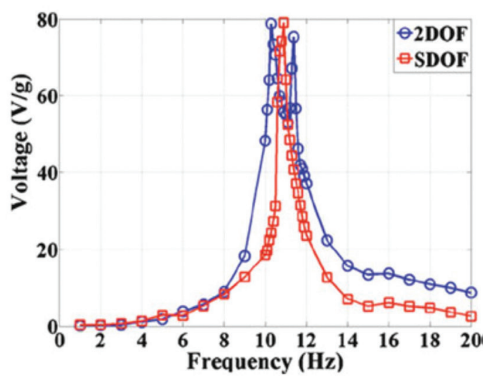

Fig. 6. (a)스프링으로 상호 결합된 에너지 하베스터를 보여주는 모식도. ${ }^{6)}$ (b)기계적으로 결합된 에너지 하베스터의 모식도. (c)기계적으로 결 합된 에너지 하베스터의 주파수에 따른 출력전압.7) 
(a)

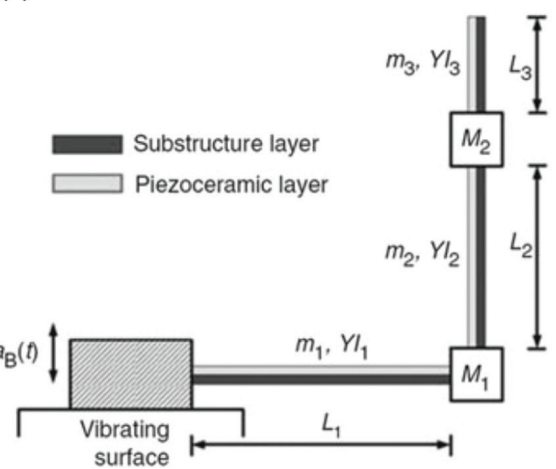

(b)

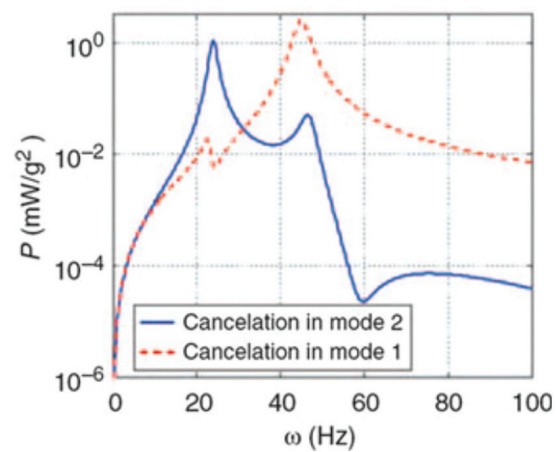

Fig. 7. (a)다중 공진을 이용한 에너지 하베스터의 모식도. (b)다중 공진을 가지는 에너지 하베스터의 주파수에 따른 출력 파워. ${ }^{8)}$

을 가중시키고, 제작 비용을 증가시키는 문제가 있다.

여러 개의 에너지 하베스터를 사용하는 대신, 하나의 에너지 하베스터 내에서 다중 모드의 공진(Multimodal resonance)을 유도함으로써, 공진 대역 폭을 증가시키는 방법도 가능하다. Fig. 5 (a)에서와 같이, 하베스터 내에 여러 개의 노드(Node)점이나 다수의 표준질량을 배치시 킴으로써, 주파수 변화에 따른 다중 모드의 공진을 유도 할 수 있다. ${ }^{5)}$ 그러나 이 경우, Fig. 5 (b)에서 보는 바와 같이, 공진 주파수들 간에 불가피하게 간격이 존재할 수 밖에 없기 때문에 공진 대역폭을 연속적으로 만드는 것은 힘든 일이다.

이러한 다중 공진 에너지 하베스터의 단점을 보완하기
위해서, 공진 간의 결합(Coupling)을 유도하는 방법이 제안되었다. Yang et al.은 개별 에너지 하베스터가 서 로 연결되었을 때 공진을 원하는 만큼 가깝게 만들 수 있 으며, 조절이 가능하다는 것을 계산을 통해 보여주었다 (Fig. 6 (a)). ${ }^{6)}$ Kim et al. 은 Fig. 6 (a), (b)에서 보는 것 과 같이, 두개의 외팔보들을 기계적으로 연결시켜 병진운 동(Translational motion) 및 회전운동(Rotational motion) 두개의 자유도를 모두 활용할 수 있게 함으로 써, 주파수 대역폭을 증가시킬 수 있었다. ${ }^{7)}$ Erturk et al. 은 Fig. 7에서 보는 것과 같이, 세 개의 외팔보와 두 개 의 표준질량이 L 형태로 차례로 결합되어 있는 $\mathrm{L}$ 모양 에 너지 하베스터(L-shaped energy harvester)를 제안하 (a)

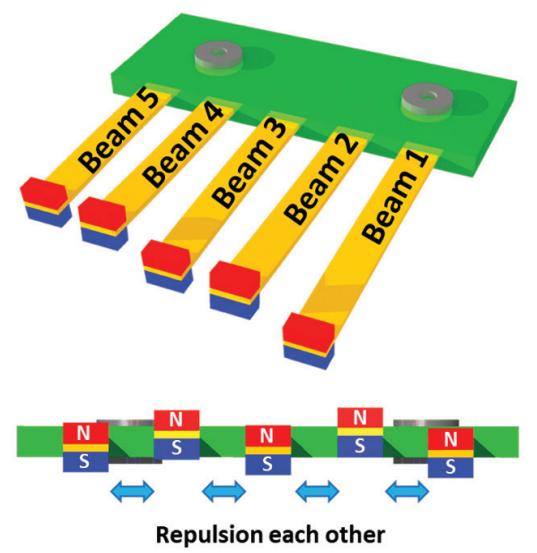

(b)

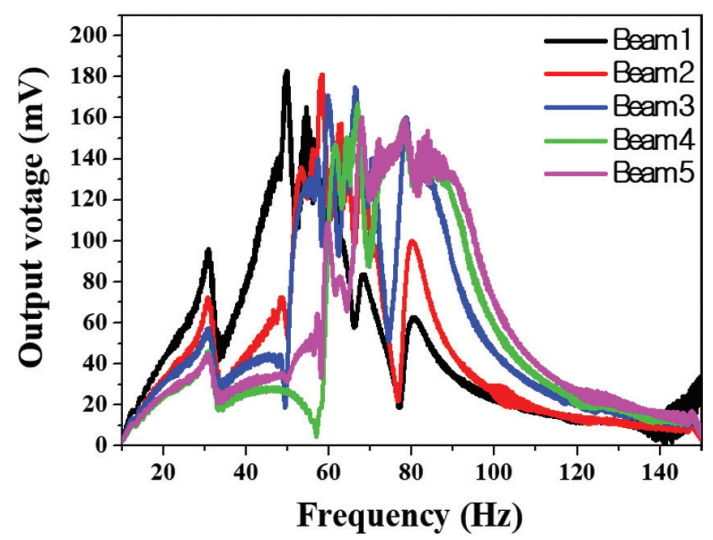

Fig. 8. (a)자기력으로 결합된 에너지 하베스터 배열의 모식도. (b)자기력으로 결합된 에너지 하베스터 배열의 주파수에 따른 출력전압.9) 
(a)

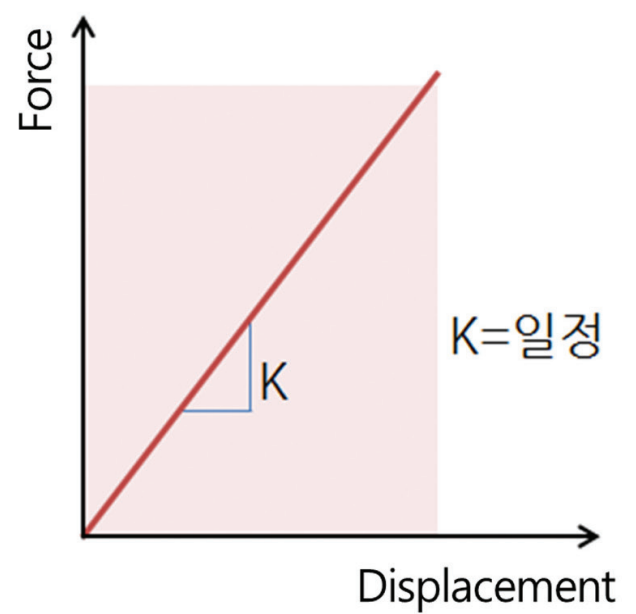

Fig. 9. (a)선형 탄성 및 (b)비선형 탄성에서의 힘-변위 상관관계.

였다. ${ }^{8)}$ 이러한 L 모양 구조에서는, Fig. 7 (b)의 주파수 응답 함수에서 볼 수 있듯이, 처음 두 개의 공진 주파수가 서로 근접하여 광대역 주파수 응답 특성을 구현할 수 있 었다. 또한 Song et al.은 자기력으로 결합된 에너지 하 베스터 배열(Magnetically coupled energy harvester array)을 개발함으로써, 일반적으로 배열된 에너지 하베 스터 보다 크게 향상된 주파수 응답 특성 및 출력 에너지 를 얻을 수 있었다. (Fig. 8). ${ }^{9)}$

다중 공진을 이용한 에너지 하베스팅은 하나의 빔에서 다중 벤딩 모드를 이용하거나, 서로 다른 공진 주파수를 나열하여 하나의 모듈로 제작하는 방법에 관한 것으로, 에너지 하베스터의 공진 주파수 대역폭을 가장 손쉽고 확 실하게 넓히는 방법 중에 하나이다. 그러나 전체 모듈에 서 실제로 동작하는 부분이 적기 때문에 에너지 밀도가 크게 떨어지는 단점이 있다. 그리고 위상 차이에 의한 전 압 상쇄가 발생하거나, 하베스터들 간에 임피던스 차이가 존재하기 때문에, 단일 모드 에너지 하베스터에 비해 복 잡한 인터페이스 전기회로가 필요하다. 뿐만 아니라, 공 진 주파수 사이의 간격이 존재하는 경우가 많기 때문에 에너지 하베스터의 결합(Coupling) 등의 방법을 이용하 여, 공진들 사이의 간격을 줄이고, 개별 공진의 대역폭을 넓이는 연구가 진행되어야 할 것이다. (b)

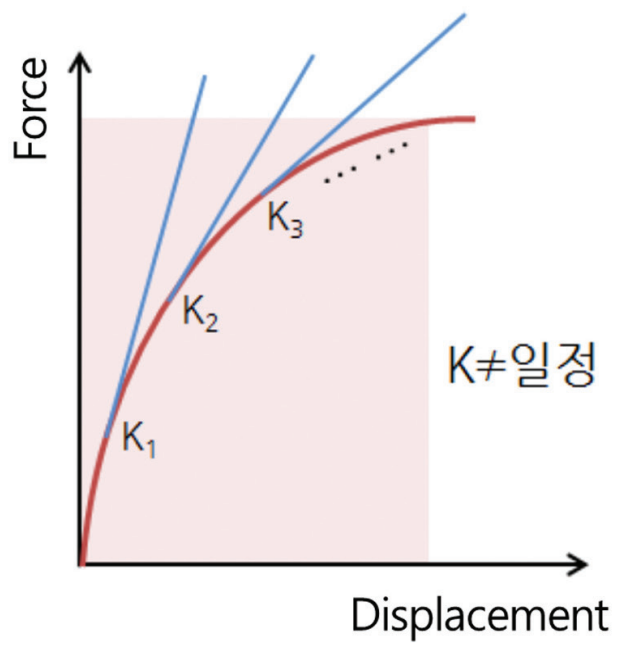

\section{3. 비선형 강성을 이용한 광대역 에너지 하베스팅}

일반적으로, 구조물에 가해지는 하중과 그에 따른 변위 가 선형적 관계가 있는 것을 선형 탄성(Linear elasticity), 그리고 가해지는 하중과 그에 따른 변위가 비선형적 관계 를 가지고 있으면, 비선형 탄성(Linear elasticity)이라고 한다. Fig. 9 (a)와 (b)는 각각 선형 탄성 및 비선형 탄성 에서의 힘-변위 상관관계를 보여주는 그래프이다. 선형 탄성에서는 구조물의 강성(Stiffness)은 항상 일정한 하 나의 값을 가지고 있으며, 비선형 탄성에서는 구조물의 강성이 하중이 변함에 따라 변하게 된다. 대부분의 에너 지 하베스터는 선형 강성(Linear stiffness) 특성을 나타 내며, Fig. 10에서와 같이 주파수 변화에 대해서도 일정 한 응답 특성을 나타낸다. 그에 반해서, 에너지 하베스터 의 강성을 경화(Hardening)시키거나 연화(Softening) 시켜, 에너지 하베스터에 비선형 강성을 유도하게 되면, Fig. 10에서와 같이, 더핑 주파수 응답(Duffing frequency response) 특성이 나타나게 되며 주파수 대 역폭이 크게 향상된다. 연화 더핑 강성(Softening Duffing stiffness)의 경우에는 주파수 하향-스윕 (Frequency down-sweep)에서 주파수 대역폭이 증가 하며, 경화 더핑 강성(Hardening Duffing stiffness)에 


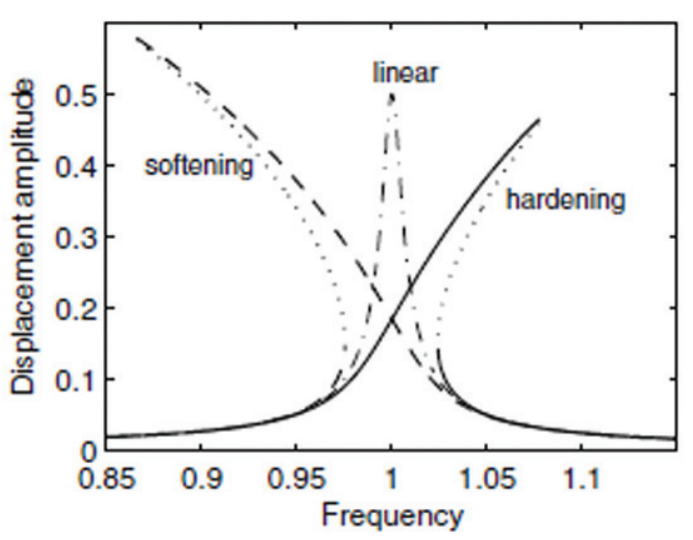

Fig. 10. 연화 및 경화 더핑 스프링의 변위 대한 주파수 응답 특성. ${ }^{10)}$

서는 주파수 상향-스윕(Frequency up-sweep)에서 대 역폭 증가 된다(Fig. 10). ${ }^{10)}$ 그러므로 에너지 하베스터에 이러한 비선형성을 유도하게 된다면, 가변 주파수 환경에 서 선형 에너지 하베스터보다 더 넓은 영역의 공진 주파 수를 얻을 수 있다. 이러한 이유 때문에 최근 비선형성을 이용한 에너지 하베스터에 대한 연구가 많은 관심을 받고 있다. 일반적으로, 강성의 비선형성은 기계적으로 구속 된 구조나 자기력에 의해 쉽게 형성될 수 있다.

Soliman et al.은 Fig. 11 (a)에 도시된 것과 같이, 외 팔보 구조의 한쪽 방향에 기계적 스토퍼(Stopper)를 설 치하여, 비선형 에너지 하베스터를 설계하였다. ${ }^{11)}$ Fig. 11 (a)의 힘-변위 관계 그래프에서 볼 수 있듯이, 이러한 구
조에서는 선형의 에너지 하베스터의 강성이 스토퍼 때문 에 움직임이 구속되어, 어느 지점부터 급격하게 꺾여 증 가함을 알 수 있다. Fig. 11 (b)는 스토퍼를 이용한 비선 형 에너지 하베스터의 주파수 응답 특성을 보여주는 그래 프이다. 주파수 하향-스윕에서는 스토퍼가 없을 때와 동 일한 대역폭을 보여주지만, 주파수 상향-스윕에서는 에 너지 하베스터의 대역폭이 증가함을 알 수 있다. 또한 주 파수 상향-스윕 동안 경화 더핑 강성에서와 비슷하게 점 프 현상 관찰되었다. 그리고 스토퍼에 의해서 하베스터의 움직임이 구속됨에 따라 공진주파수에서의 최대 출력전 압은 감소하였다. 이러한 기계적 구속을 이용한 비선형 에너지 하베스터에서는 공진 주파수 대역폭을 증가시킬 수 있지만, 그에 따른 최대 출력전압이 감소하는 단점이 있다.

대부분의 비선형 에너지 하베스터는 경화 또는 연화 강 성 중 하나의 특성을 나타내는 것이 일반적이다. Stanton et al.은 세개의 자석을 이용하여, 하나의 소자에서 경화 와 연화 비선형 응답 특성이 양쪽방향으로 일어날 수 있 는 에너지 하베스터를 개발하여 보고하였다. ${ }^{12)}$ 이러한 에 너지 하베스터는 Fig. 12 (a)의 사진에서 볼 수 있듯이, 반대 극성을 띠는 2 개의 고정 자석들과 이들 자석들과 자 기장에 의해 상호작용이 가능하도록 압전 외팔보 끝에 부 착된 자석 표준질량으로 구성된다. 이러한 시스템은 다음 의 기계적 더핑 방정식(Mechanical Duffing equations) (a)

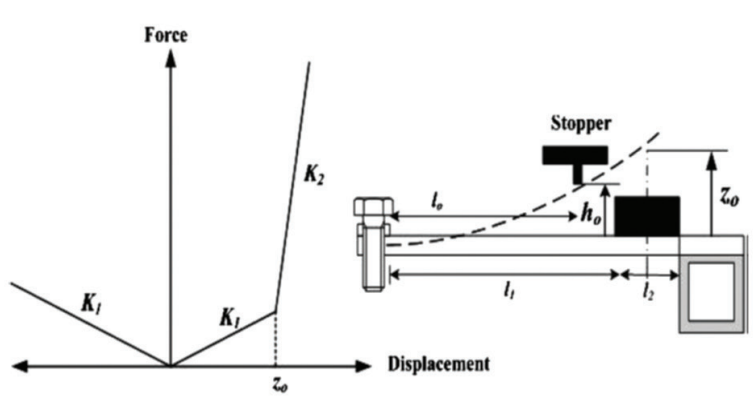

Fig. 11. (a)기계적 스토퍼를 이용한 에너지 하베스터의 비선형 특성 및 구조도. 파수 응답 특성.11 (b)

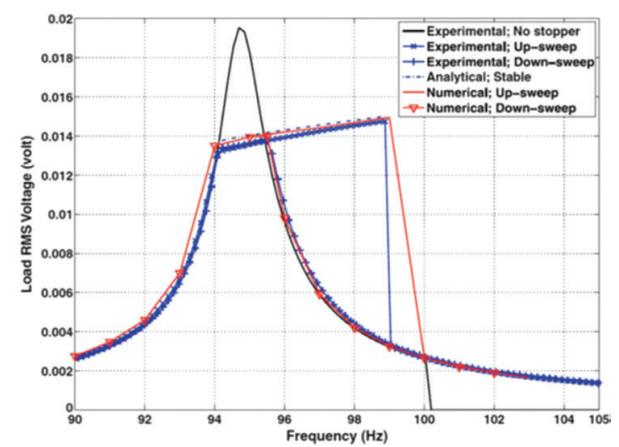

(b)기계적 스토퍼를 이용한 비선형 에너지 하베스터의 주 
(a)

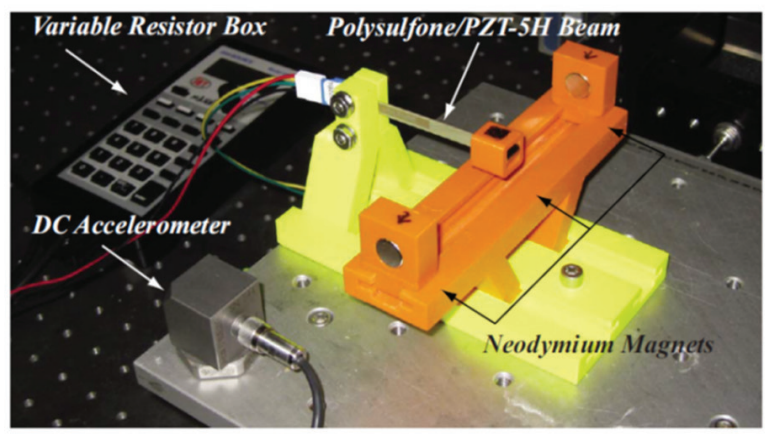

(b)

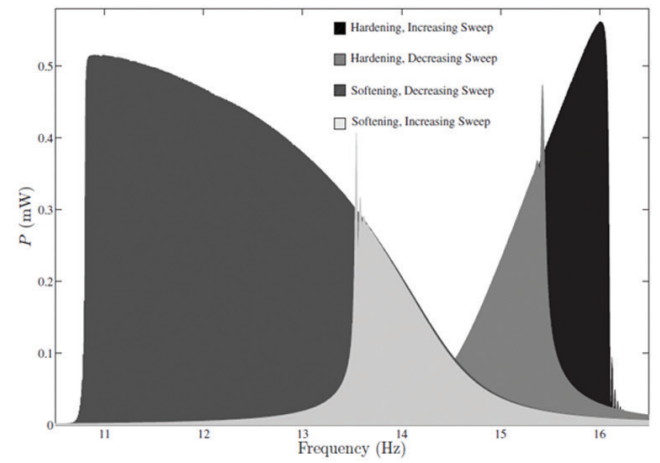

Fig. 12. (a)자석을 이용한 경화 및 연화 강성 양방향 비선형 에너지 하베스터의 구조를 보여주는 사진. (b)경화 및 연화 강성 양방향 비선형 에너지 하베스터의 주파수 응답 특성. ${ }^{12)}$

(a)

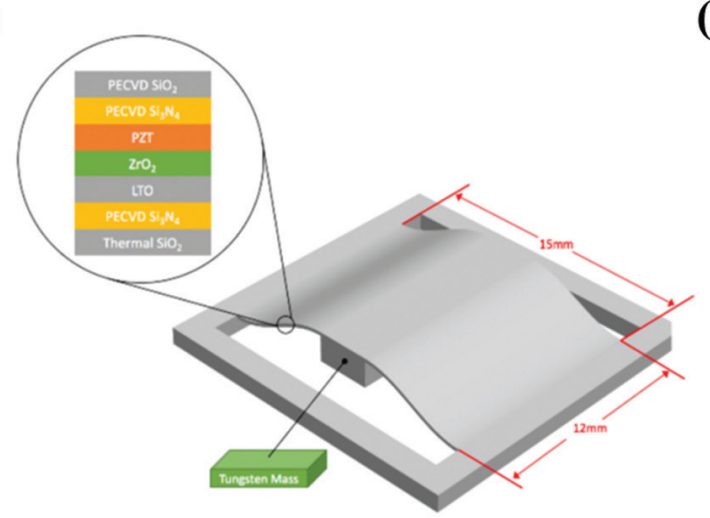

(c)

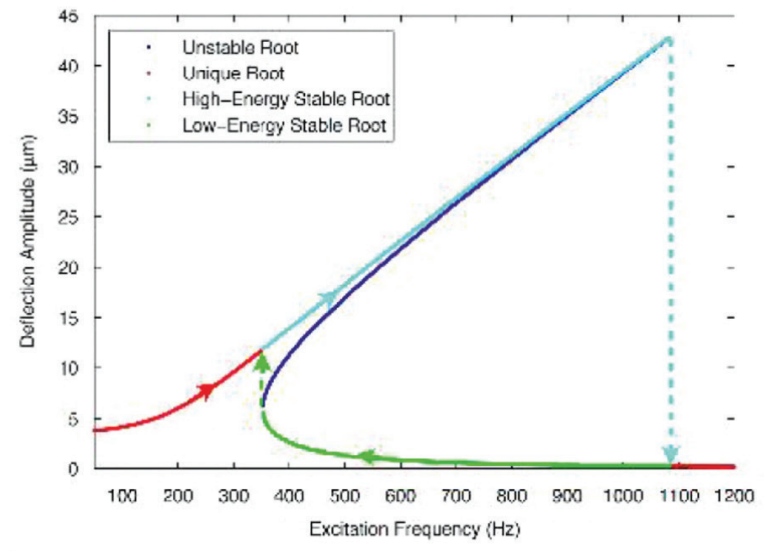

(b)

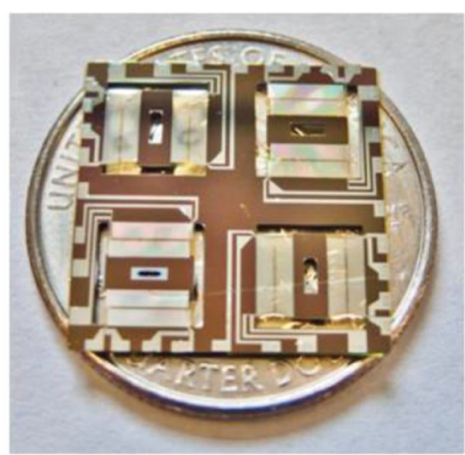

(d)

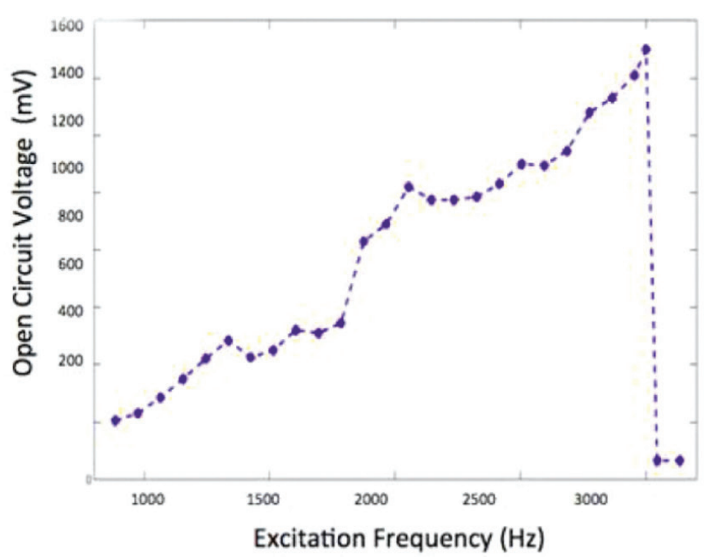

Fig. 13. (a)버클링된 구조를 가지는 비선형 MEMS 에너지 하베스터의 구조도. (b)제작된 비선형 MEMS 에너지 하베스터의 사진. 비선형 MEMS 에너지 하베스터의 주파수 변화에 따른 개방 회로 전압 (c)시뮬레이션값 및 (d)측정값. 
으로 모델링 될 수 있다.

$$
m \ddot{z}+d \dot{z}+\alpha z \pm \beta z^{3}=-m \ddot{y}
$$

여기에서 $\alpha$ 와 $\beta$ 는 자석들 간의 거리에 대한 결과값이 며, $Z^{3}$ 의 부호는 경화 강성에서는 양 $(+)$ 이고, 연성 강성 에 대해서는 음(-)이다. Fig. 12 (b)의 주파수 응답특성 에서와 같이, 이러한 구조에서는 경화 강성과 연화 강성 현상이 모두 발생하여 공진 주파수 대역폭을 양방향으로 넓힐 수 있었다.

자력을 이용한 비선형 에너지 하베스터는 손쉽게 소자 에 비선형성을 유도할 수 있는 반면, 작은 크기의 MEMS 에너지 하베스터에서는 자석의 설치 및 부착에 어려움이 있을 수 있다. 그래서 Hajat et al. 은 양끝단이 고정된 빔 구조에서 스트레칭 스트레인(Stretching strain)을 유발 하여, 버클링(Buckling)된 구조를 가지는 비선형 MEMS 에너지 하베스터를 개발하여 보고하였다. ${ }^{13)}$ Fig. 13 (a) 는 버클링된 구조를 가지는 비선형 MEMS 에너지 하베 스터의 구조를 보여주는 모식도이며, Fig. 13 (b)는 완성 된 에너지 하베스터를 보여주는 사진이다. Fig. 13 (c)와 (d)의 시뮬레이션 및 측정된 주파수 응답 특성 그래프에 서 보는 바와 같이, 버클링된 구조에서는 경화 더핑 강성 특성이 나타났으며, 선형 에너지 하베스터 대비 $50 \%$ 이상 향상된 공진 주파수 대역폭을 보여주었다. 이러한 버클링 된 구조의 에너지 하베스터는 복잡한 조립과정이나 추가 공정없이, 기존의 $\mathrm{MEMS}$ 공정을 이용하여 비선형 에너 지 하베스터를 제작할 수 있다는데 큰 의미가 있다.

비선형 강성을 이용한 에너지 하베스터는 단일 구조에 서 공진 주파수 대역폭을 크게 증가시킬 수 있다는데 큰 장점이 있다. 그러나 조화 진동(Harmonic vibration)의 주파수 스윕(Sweep)에서만 넓은 주파수 응답 특성이 나 타날 수 있으며, 불규칙 진동(Random vibration)에서는 이러한 특성이 나타나지 않을 수도 있다. 뿐만 아니라, 주 파수 스윕의 상 - 하향 방향에 따라 주파수 응답 특성이 다르게 나타난다. 또한 비선형 거동은 진동 크기가 클 때 더 명확히 나타나며, 진폭이 작을 때는 이런 특성이 나타 나지 않을 수 있다. 이처럼 비선형 강성은 특별한 조건에
서만 형성될 수 있기 때문에, 주변 환경의 영향을 최소화 시킬 수 있는 방안에 대한 연구가 지속되어야 할 것이다.

\section{4. 자가 공진 튜닝 방법을 이용한 광대역 에너지 하베스팅}

에너지 하베스터가 주변의 진동 환경에 맞춰 스스로 공 진을 감지하고, 하베스터의 고유 진동수를 이에 맞춰 튜 닝(Tuning)할 수 있다면, 여러가지 면에서 가장 효율적 인 방법일 것이다. 그러나 공진을 감지하고 에너지 하베 스터의 고유진동수를 튜닝하기 위해서는 필연적으로 사 람의 개입이 필요하거나, 추가적으로 에너지를 소모해야 된다. 센서 및 액츄에이터를 이용하여, 에너지 하베스터 의 고유진동수를 능동적으로 튜닝(Active tuning)하는 메카니즘에 대한 연구들이 다수 발표되었으나, 추가적인 전기 에너지 소모량이 많거나, 심지어는 발전 에너지량보 다 많은 경우가 대부분이었다. 그러므로 실제적인 응용 측면에서 이러한 능동 튜닝 방법은 부적합하다고 할 수 있다.

최근 능동 튜닝 방법과 달리 추가적이 에너지 투입 없 이, 기계적 스위칭 메커니즘이나, 원심력에 의해 하베스

(a)

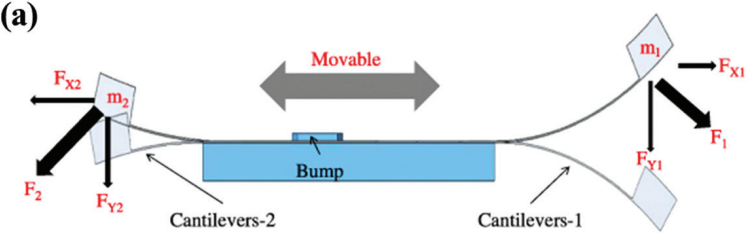

(b)

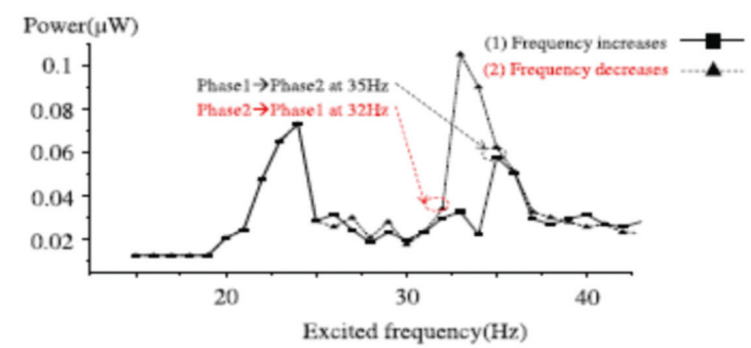

Fig. 14. (a)스위칭 메커니즘을 이용한 자가 공진 조절 에너지 하베스 터 모식도. (b)주파수 변화에 따른 자가공진조절 에너지 하 베스터의 주파수변화에 따른 출력 파워. ${ }^{14)}$ 
(a)

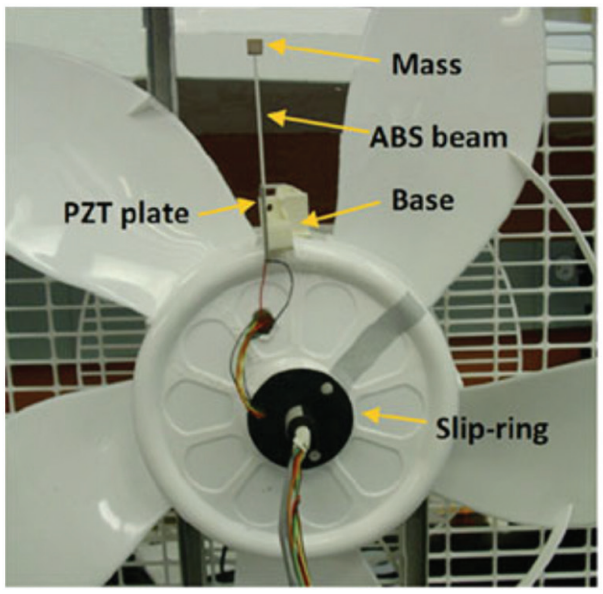

(b)

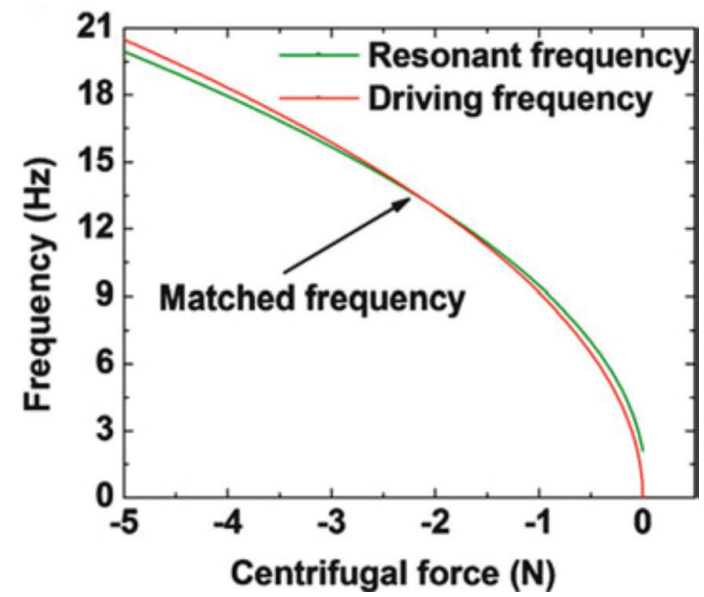

Fig. 15. (a)자가공진조절 에너지 하베스터의 사진. (b)원심력 변화에 따른 에너지 하베스터의 고유진동수 변화.15)

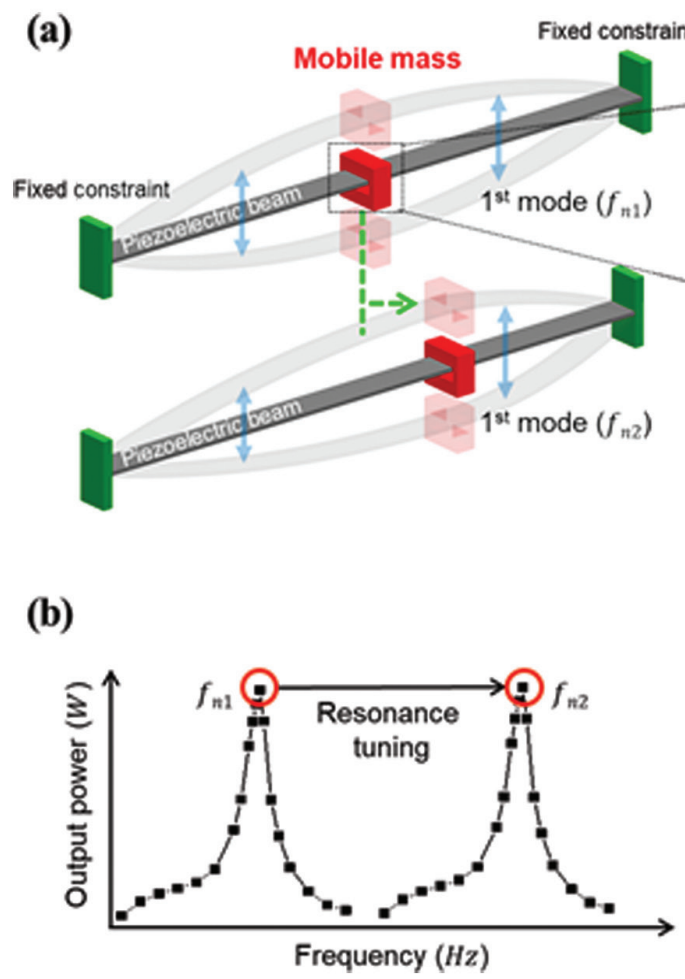

Cross section

\begin{tabular}{c}
$\begin{array}{c}\text { Piezoelectric } \\
\text { Beam }\end{array}$ \\
\hline$\uparrow$ Gap \\
\hline Mobile mass
\end{tabular}

(c)
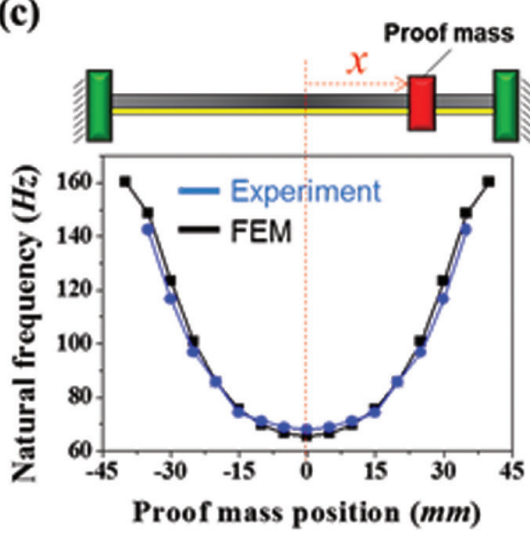

Fig. 16. (a)이동 표준질량을 이용한 자가공진조절 에너지 하베스터의 구조를 보여주는 모식도. (b)고유진동수 튜닝을 이용한 자가공진조절의 원리를 보여주는 그래프. (c)양끝이 고정된 빔 구조에서 표준질량의 위치에 따른 고유진동수 변화.

터의 강성을 스스로 조절하는 방법 등과 같은 자가 공진 튜닝(Self-resonance tuning) 메커니즘에 대한 연구들 이 보고되었다. Jo et al. 는 Fig. 14 (a)에 도시된 바와 같
이, 길이가 다른 외팔보 두개가 시소처럼 서로 연결된 디 자인을 선보였다. ${ }^{14)}$ 이 연결된 외팔보들은 양쪽의 표준질 량이 진동할 때의 수평 관성력에 의해 좌우로 움직일 수 
(a)

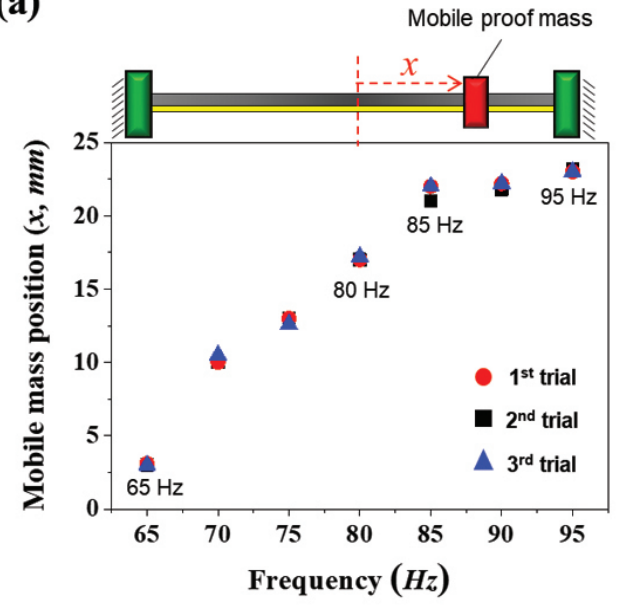

(b)

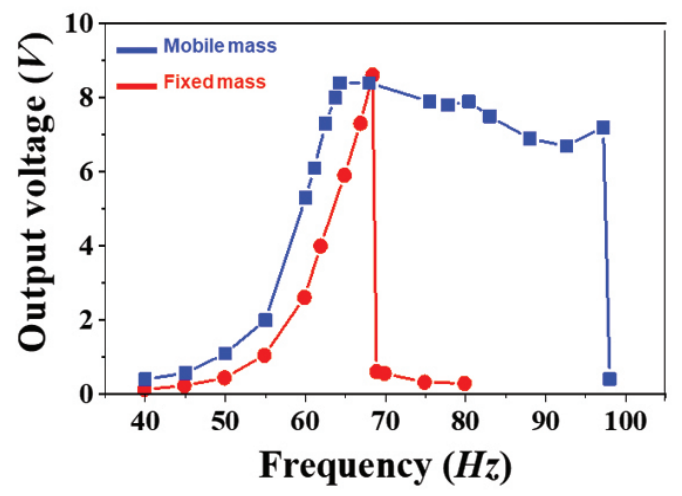

(c)
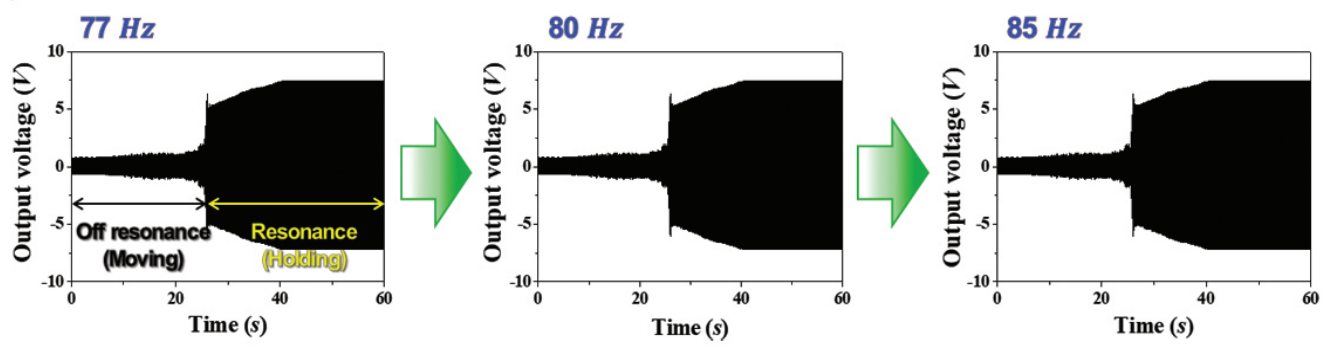

Fig. 17. (a)가해준 진동 주파수에 따른 이동 표준질량의 멈춘 위치. (b)고정 표준질량 및 이동 표준질량을 가지는 에너지 하베스터의 주파수 응답 특성. (c)가해준 진동 주파수를 순차적으로 변화시킬 때의 시간에 따른 출력전압 변화.

있다. 외팔보의 수평 관성력은 진동 주파수에 따라 변하 며, 외팔보의 고유 진동수가 진동 주파수와 일치 할 때 최 대가 된다. 양쪽 수평 관성력의 차이에 의해 서로 다른 두 개의 고유진동수로 변환될 수 있다. 이 때문에 추가적인 전력소모 없이 자가공진조절이 가능하다. Fig. 14 (b)에 나타난 것처럼 각 외팔보는 진동 주파수가 변함에 따라 두 개의 공진 피크가 있다. 공진 주파수는 2 개의 위상 사 이에서만 전환하기 때문에 연속 주파수 범위를 커버 할 수는 없지만, 이러한 장치는 자가 공진 튜닝 메커니즘이 없는 기존의 외팔보 에너지 하베스터보다 횔씬 효율적임 을 알 수 있다.

$\mathrm{Gu}$ et al.는 회전 운동에 적용 가능한 자가 공진 튜닝 에너지 하베스터를 보고하였다. ${ }^{15)} \mathrm{Fig} .15$ (a) 같이, 외팔 보 구조의 에너지 하베스터를 회전반경 바깥방향으로 향 하도록 설치하여, 에너지 하베스터의 강성이 원심력에 따
라 변하도록 설계함으로써, 공진 주파수가 조정될 수 있 도록 하였다. 에너지 하베스터의 구동 주파수와 고유 진 동수 둘 다 원심력과 관련이 있기 때문에, 에너지 하베스 터의 고유 진동수와 구동 주파수가 $13.2 \mathrm{~Hz}$ 에서 정확하 게 일치하도록 설계하였다. 이로 인해 $6.2 \mathrm{~Hz} \sim 16.2 \mathrm{~Hz}$ 의 범위 내에서 Fig. 15 (b)와 같이 두 주파수가 거의 일 치함을 알 수 있다. 따라서, 에너지 하베스터는 회전수 변 화에 따라 구동 주파수가 변하더라도, 항상 공진이나 공 진 부근에서 동작하게 된다. 이러한 자가공진조절 에너지 하베스터는 튜닝되지 않은 하베스터의 공진 대역폭(0.61 $\mathrm{Hz})$ 대비 훨씬 더 넓은 대역폭 $(8.2 \mathrm{~Hz})$ 을 나타내었다. 그 러나 이 장치는 회전 동작에만 적용 할 수 있는 큰 단점이 있다.

최근 한국과학기술연구원(KIST)에서는 움직임이 가능 한 표준질량의 액츄에이션 거동을 이용하여, 새로운 자가 
공진 튜닝 메커니즘을 개발하였다. Fig. 16 (a), (b)는 움 직임이 가능한 표준질량(Mobile poof mass)을 이용한 자가공진조절 에너지 하베스터의 구조 및 원리를 보여주 는 모식도이다. Fig. 16 (c)와 같이, 양 끝이 고정된 빔 구 조에서는 표준질량의 위치에 따라서 고유진동수가 순차 적으로 변할 수 있다. 표준질량에 미세한 틈을 만들어 외 부에서 진동이 가해지면 표준질량이 빔 위를 따라 움직이 게 만들었다. 표준질량이 외부진동에 의해서 움직이다가 공진 위치에 도달하게 되면, 빔의 변위가 크게 증가하여 그 지점에 고정되어 공진 상태로 지속적으로 동작하게 된 다. 이러한 원리를 통해 자가 공진 튜닝이 가능하게 된다. Fig. 17 (a)에 도시된 바와 같이, 움직이는 표준질량이 고 정되는 위치는 외부진동의 주파수에 의해서 결정되고, 여 러 번의 반복에 의해서도 그 위치는 일정함을 알 수 있다. Fig. 17 (b)는 고정된 표준질량 및 움직임이 가능한 표준 질량을 가진 에너지 하베스터들의 주파수 응답특성을 보 여주는 그래프이며, 움직임이 가능한 표준질량의 에너지 하베스터가 훨씬 넓은 공진주파수 대역 $(35 \mathrm{~Hz})$ 을 가지고 있음을 알 수 있다. 또한 Fig. 14(c)에서처럼, 구동 주파 수가 변하더라도 에너지 하베스터가 다시 스스로 공진을 조절할 수 있음 알 수 있다. 이는 간단한 구조에서 넓은 대역의 구동 주파수에 맞춰 스스로 공진을 튜닝할 수 있 는 최초의 연구결과로, 기술 발전을 통해 진동형 에너지 하베스터의 실용화에 크게 기여할 것으로 기대된다.

자가공진조절 방법을 이용한 에너지 하베스터는 추가 적인 에너지 투입이나 사람의 개입이 필요 없기 때문에 광 장히 효율적이며, 다중 공진을 이용하는 방법에 비해 비 교적 단순한 구조를 가지고 있다. 또한, 비선형성을 이용 한 에너지 하베스터와 달리, 구동 조건에 많은 영향을 받 지 않고, 공진 주파수 대역의 향상에 따른 출력 저하가 거 의 없기 때문에 높은 에너지 밀도를 가지는 장점이 있다. 그러나 공진 주파수 변환 속도가 비교적 느리기 때문에 자 동차 엔진과 같이 지속적으로 진동 주파수가 변화하는 환 경에는 부적합하다고 할 수 있다. 에너지 하베스터의 구 조개선 및 새로운 자가공진조절 메커니즘 개발을 통해 공 진 주파수 변환 속도가 빠르며, 공진 주파수 대역을 좀 더 넓힐 수 있는 방법에 연구가 필요할 것으로 생각된다.

\section{5. 맺음말}

기존의 압전 에너지 하베스터는 좁은 고유 진동수를 갖 기 때문에, 광범위한 주파수 대역을 가지는 실제 진동에 적용하기 어려운 문제가 있었다. 본고에서는 이 문제를 해결하기 위한 여러가지 광대역 에너지 하베스터 개발 방 법들과 대표적인 연구결과에 대해 살펴보았다. 에너지 하 베스터의 주파수 응답 특성을 향상시키기 위한 방법은 다 중 공진, 비선형 강성, 자가 공진 튜닝의 크게 세가지로 나누어 볼 수 있으며, 각 방법들마다 뚜렷한 장 - 단점을 가지고 있다. 다중 공진을 이용한 광대역 에너지 하베스 터는 공진 주파수 대역폭을 가장 쉽고 확실하게 넓히는 방법이지만, 에너지 밀도가 크게 떨어지는 단점이 있다. 반면에, 비선형 강성을 이용한 광대역 에너지 하베스터의 경우는 하나의 소자에서 광대역 공진을 얻을 수 있지만, 진동 환경에 따라 공진 대역폭이 변하는 문제가 있다. 그 리고 주변 환경에 따라 에너지 하베스터가 추가적인 에너 지 소모없이 스스로 공진 주파수를 조정하는 자가 공진 튜닝 방법은 여러 방법들 중에서 최근 가장 주목 받고 있 지만, 이 또한 튜닝 속도가 느려 응용 범위가 제한될 수가 있다. 현재까지 실용화가 가능한 광대역 에너지 하베스터 에 대한 근본적인 해결책은 제시되지 않았다. 이를 위해 서, 새로운 메커니즘 개발이나, 기존 방법의 문제점을 해 결하기 위한 지속적인 연구가 필요하겠다. 아울러, 압전 에너지 하베스터의 실제 적용환경에서 동작 특성 및 구체 적인 실제 적용 연구가 많이 진행되어야 할 것으로 판단 된다.

\section{참고문헌}

1. H. K. Cho, D. H. Kim, H. S. Sin, C. H. Cho \& S. Han, "Flexible Thermoelectric Device Using Thick Films for Energy Harvesting from the Human Body." J. Korean Ceram. Soc., 54 [6] 518-524 (2017).

2. S. Priya et al. "A review on piezoelectric energy harvesting: materials, methods, and circuits." Energy Harvesting and Systems, 4 [1] 3-39 (2017).

3. C. S. Han, T. H. Lee, G. M. Kim, D. Y. Lee, \& Y. S. Cho, "Piezoelectric Energy Harvesting Characteristics 
of GaN Nanowires Prepared by a Magnetic FieldAssisted CVD Process.” J. Korean Ceram. Soc., 53 [2] 167-170 (2016).

4. J. Twiefel \& H. Westermann., "Survey on broadband techniques for vibration energy harvesting." J. Intell. Material Syst. Struct., 24 [11] 1291-1302 (2013).

5. Y. Tadesse, S. Zhang \& S. Priya, "Multimodal energy harvesting system: piezoelectric and electromagnetic." J. Intell. Material Syst. Struct., 20 [5] 625-632 (2009).

6. Z. Yang, \& J. Yang, "Connected vibrating piezoelectric bimorph beams as a wide-band piezoelectric power harvester." J. Intell. Material Syst. Struct., 20 [5] 569-574 (2009).

7. I. H. Kim, H. J. Jung, B. M. Lee \& S. J. Jang, "Broadband energy-harvesting using a two degreeof-freedom vibrating body." Appl. Phys. Lett., 98 [21] 214102 (2011).

8. A. Erturk, J. M. Renno \& D. J. Inman, "Modeling of piezoelectric energy harvesting from an L-shaped beam-mass structure with an application to UAVs." J. Intell. Material Syst. Struct., 20 [5] 529-544 (2009).

9. H. C. Song et al. "Broadband dual phase energy harvester: Vibration and magnetic field." APPL
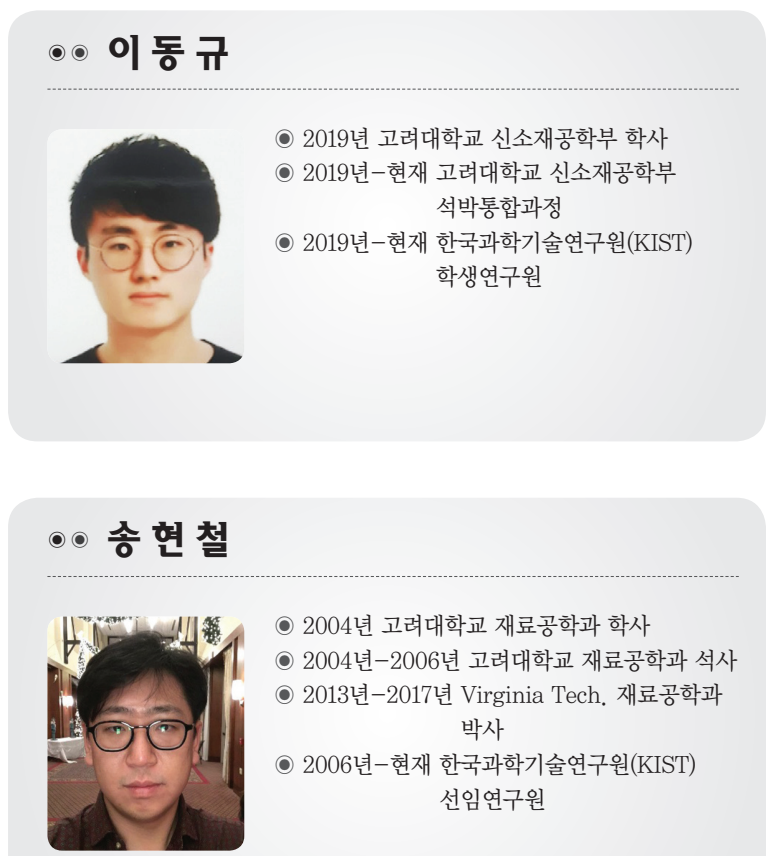

( 2004년 고려대학교 재료공학과 학사

( 2004년-2006년 고려대학교 재료공학과 석사

0 2013년-2017년 Virginia Tech. 재료공학과 박사

○ 2006년-현재 한국과학기술연구원(KIST) 선임연구원
ENERG, 225 1132-1142 (2018).

10. N. Elvin \& A. Erturk, "Advances in energy harvesting methods.” Springer Science \& Business Media (2013).

11. M. Soliman, E. Abdel-Rahman, E. El-Saadany \& R. Mansour, "A wideband vibration-based energy harvester." J Micromech Microeng; 18 [11] 115021 (2008).

12. S. C. Stanton, C. C. McGehee \& B. P. Mann, "Reversible hysteresis for broadband magnetopiezoelastic energy harvesting." Appl. Phys. Lett., 95 [17] 174103 (2009).

13. A. Hajati \& S. G. Kim, "Ultra-wide bandwidth piezoelectric energy harvesting." Appl. Phys. Lett., 99 [8] 083105 (2011).

14. S. E. Jo, M. S. Kim \& Y. J. Kim, "A resonant frequency switching scheme of a cantilever based on polyvinylidene fluoride for vibration energy harvesting." Smart Mater. Struct., 21 [1] 015007 (2011).

15. L. Gu \& C. Livermore, "Passive self-tuning energy harvester for extracting energy from rotational motion.” Appl. Phys. Lett., 97 [8] 081904 (2010).

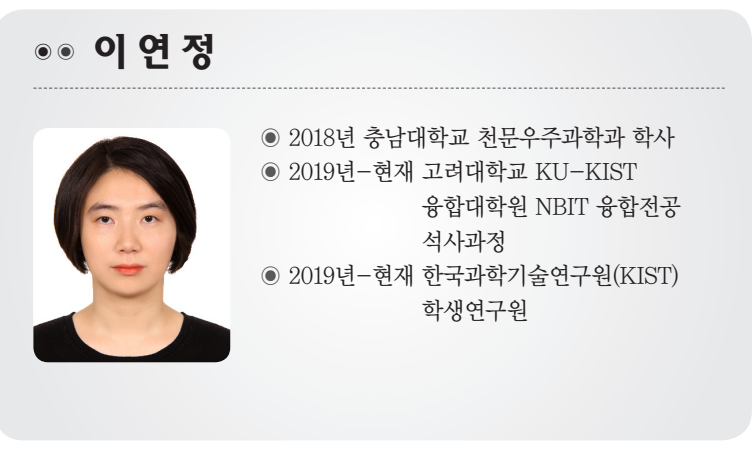

